\title{
MODEL PEMBELAJARAN PROBLEM BASED LEARNING DALAM PEBELAJARAN SEJARAH UNTUK MENINGKATKAN KARAKTER SISWA DI KELAS X SMA NEGERI 3 BANJAR
}

\author{
Andri Purwanto ${ }^{1}$, Runalan Soedarmo ${ }^{2}$, Aan Suryana ${ }^{3}$. \\ 1,2,3 Program Studi Pendidikan Sejarah, Universitas Galuh, Jl. R. E. Martadinata No.150, Ciamis, Indonesia \\ Email: ap667994@gmail.com, runalansoedarmo@gmail.com, aansuryana64@gmail.com
}

\begin{abstract}
This Classroom Action Research (PTK) uses a Problem Based Learning (PBL) model consisting of two cycles. Data collection techniques of the study are observations, documents from teachers and school principals, documentation, questionnaires, and tests. The purpose of this study is to describe and determine the results of using the PBL model to improve the students' character of class X SMA Negeri 3 Banjar. The results shows that the application of the Problem Based Learning (PBL) model is quite well applied to History subjects at SMA Negeri 3 Banjar. The reason is that at the beginning of learning, real-world problems have been presented, then investigated to find out solutions of problems solving. The ultimate goal of implementing this learning model is to achieve the improvement of students' character properly. This can be seen from the results of observations during the learning process and through the questionnaires given. In conclusion, it reveals the percentage of positive statement that $77 \%$ are approved, $5.5 \%$ are rejected, and $16.6 \%$ are taken as normal or neutral. Regarding the percentage of negative statements, $38.9 \%$ are approved, $25 \%$ are rejected and $36 \%$ are neutral.
\end{abstract}

Keywords: Problem Based Learning Model; Character

\begin{abstract}
ABSTRAK
Penelitian ini merupakan Penelitian Tindakan Kelas (PTK) dengan menggunakan model pembelajaran Problem Based Learning (PBL) yang terdiri dari dua siklus. Teknik pengumpulan data dalam penelitian ini adalah pengamatan, dokumen dari guru dan kepala sekolah, dokumentasi, angket, dan tes. Tujuan dari penelitian ini adalah untuk mendeskripsikan dan mengetahui hasil dari penggunaan model PBL untuk meningkatkan karakter siswa di kelas X SMA Negeri 3 Banjar. Hasil penelitian menunjukkan bahwa penerapan model Problem Based Learning (PBL) cukup baik diterapkan pada mata pelajaran sejarah di SMA Negeri 3 Banjar. Hal ini dikarenakan diawal pembelajaran telah disajikan masalah dunia nyata, selanjutnya diselidiki untuk diketahui solusi dari pemecahan permasalahannya. Tujuan akhir penerapan model pembelajaran ini adalah tercapainya peningkatan karakter siswa dengan baik. Hal ini dapat dilihat dari hasil observasi selama pembelajaran berlangsung dan melalui angket yang diberikan. Kesimpulannya adalah $77 \%$ pernyataan positif disetujui, 5,5\% pernyataan positif ditolak, dan $16,6 \%$ pernyataan positif ditanggapi biasa saja atau netral. Selanjutnya, pernyataan negatif $38,9 \%$ disetujui, $25 \%$ pernyataan ditolak, dan $36 \%$ pernyaataan ditanggapi netral.
\end{abstract}

Kata Kunci: Model Problem Based Learning; Karakter

Cara sitasi: Purwanto, A., Soedarmo, R.R., \& Suryana, A., (2021). Model pembelajaran problem based learning dalam pebelajaran sejarah untuk meningkatkan karakter siswa di kelas $x$ sma negeri 3 banjar. J-KIP (Jurnal Keguruan dan IImu Pendidikan), 2 (2), 39-46. 


\section{PENDAHULUAN}

Berpikir pada dasarnya adalah fitrah yang dimiliki manusia, karena dengan berpikir manusia dapat menghadapi tantangan zaman, melakukan perubahan dan menghadapi perubahan itu sendiri. Menurut Sagala (2011) berpikir merupakan suatu kegiatan mental yang dialami seseorang bila mereka dihadapkan pada suatu masalah atau situasi yang harus dipecahkan. Pendapat ini menunjukkan bahwa ketika seseorang merumuskan suatu masalah, memecahkan masalah, ataupun ingin memahami sesuatu, maka ia melakukan suatu aktivitas berpikir. Kemampuan berpikir logis, analitis, sistematis, kritis maupun bekerja sama ini dapat dikembangkan dan dilatih secara terus menerus melalui dunia akademis/pendidikan. Hal ini pula yang diamanatkan oleh UU SISDIKNAS No. 20 tahun 2003 yaitu usaha sadar dan terencana untuk mewujudkan suasana belajar dan proses pembelajaran agar peserta didik secara aktif mengembangkan potensi dirinya, memiliki kekuatan spiritual keagamaan, pengendalian diri, kepribadian, kecerdasan, akhlak mulia, serta keterampilan yang diperlukan dirinya dan masyarakat (Tim pengembang IImu Pendidikan FIP-UPI, 2007). Dengan demikian, pada dasarnya hakekat tujuan pendidikan nasional adalah mencerdaskan kehidupan bangsa dan mengembangkan manusia Indonesia seutuhnya, yaitu manusia yang beriman dan bertaqwa terhadap Tuhan Yang Maha Esa dan berbudi pekerti luhur, memiliki pengetahuan dan keterampilan, kesehatan jasmani dan rohani, kepribadian yang mantap dan mandiri serta rasa tanggung jawab kemasyarakatan dan kebangsaan (Ulfa, 2016). Dengan demikian pendidikan merupakan suatu hal yang penting dalam kehidupan manusia yang menjadikan manusia lebih berilmu, berwawasan luas dan mampu berfikir kritis. Belajar merupakan suatu proses dalam kehidupan manusia yang berlangsung sepanjang hayat (Asmara, Heryati \& Patonah, 2021).

Salah satu pendidikan terpenting yang dapat diberikan adalah pendidikan sejarah, karena melalui pendidikan sejarahlah peserta didik akan memahami pentingnya mempelajari peristiwa masa lalu sebagai gambaran masa depan, dengan belajar dari kejadian yang telah lampau. Menurut Hasan (2011) pendidikan sejarah merupakan materi pendidikan yang teramat penting untuk mencapai empat tujuan. Pertama, memberikan materi pendidikan yang mendasar, mendalam dan berdasarkan pengalaman nyata bangsa di masa lalu guna membangun kesadaran dan pemahaman tentang diri dan bangsanya. Kedua, merupakan materi pendidikan yang khas dalam membangun kemempuan berpikir logis, kritis, analitis, dan kreatif karena berkenaan dengan sesuatu yang sudah pasti dalam kehidupan bangsa di masa lampau dan selalu berkenaan dengan perilaku manusia yang dikendalikan oleh cara berpikir logis, kritis, analitis dan kreatif yang sesuai dengan tantangan kehidupan yang dihadapi pada masanya. Ketiga, menyajikan materi dan contoh keteladanan, kepemimpinan, kepeloporan, sikap dan tindakan manusia dalam kelompoknya yang menyebabkan terjadinya perubahan-perubahan dalam kehidupan manusia tersebut. Dan Keempat, kehidupan manusia selalu terkait dengan masa lampau karena walaupun hasil tindakan dalam menjawab tantangan bersifat final tetapi hasil dari tindakan tersebut selalu memiliki pengaruh yang tidak berhenti hanya untuk masanya tetapi berpengaruh terhadap masyarakat tadi dalam menjalankan kehidupan barunya, dan oleh karenanya peristiwa sejarah menjadi "bank of examples" untuk digunakan dan disesuaikan sebagai tindakan dalam menghadapi tantangan kehidupan masa kini.

Berdasarkan pendapat tersebut, maka proses pendidikan, khususnya pengajaran sejarah, ibarat mengajak peserta didik menengok ke belakang dengan tujuan melihat ke depan, sehingga dengan mempelajari nilai-nilai kehidupan masyarakat di masa lampau, diharapkan peserta didik mencari atau mengadakan seleksi terhadap nilai-nilai itu, mana yang relevan atau dapat dikembangkan dalam menghadapi tantangan zaman yang kompleks di masa kini maupun yang akan datang. Hal ini sejalan dengan pendapat Kartodidjo (1988) dalam Susanto (2014), bahwa dalam rangka pembangunan bangsa, pengajaran sejarah tidak semata-mata berfungsi memberikan pengetahuan sejarah sebagai kumpulan informasi fakta sejarah, tetapi juga bertujuan menyadarkan anak didik atau membangkitkan kesadaran sejarahnya. Untuk mencapai tujuan tersebut maka sejarah yang diajarkan haruslah mengedepankan nilai-nilai kehidupan, bukan sejarah hapalan yang hanya menyuguhkan nama, tempat, angka tahun dan peristiwa semata. Pembelajaran sejarah 
semacam ini perlu sekali untuk diterapkan agar pembelajaran sejarah tidak kering dari makna dan dapat memberikan penyadaran terhadap pembelajar/peserta didik.

Menurut Zuhdi, (2010) dalam Susanto (2014) pembelajaran sejarah yang baik akan membentuk pemahaman sejarah. Pemahaman sejarah memberi petunjuk kepada kita untuk melihat serangkaian peristiwa masa lalu sebagai sistem tindakan masa lalu sesuai dengan jiwa jamannya, akan tetapi memiliki sekumpulan nilai edukatif terhadap kehidupan sekarang dan akan datang. Sehubungan dengan pendidikan karakter maka pembelajaran sejarah harus diarahkan untuk memahami dan menghayati nilai-nilai karakter yang tercermin dalam setiap cerita sejarah. Bukankah "membentuk watak" seperti yang telah dipaparkan dalam berbagai fakta historis di atas merupakan karakter yang terbentuk di dalam dinamika sejarah bangsa Indonesia. Ada tiga hal penting dalam pendidikan karakter, yaitu; unsur pengetahuan tentang yang baik (knowing the good), tindakan yang baik (doing the good), dan unsur motivasi internal dalam melakukan yang baik (loving the good) (Lickona (2006) dalam Koesoema, 2010). Dengan demikian domain pendidikan karakter menurut Lickona menyangkut otak, tangan dan hati. Pada dasarnya perjalanan sejarah itu sendiri adalah perjalanan membentuk karakter bangsa, sehingga pendidikan yang dilakukan haruslah memperhatikan nilai-nilai karakter dalam sejarah bangsa yang menyangkut otak (pemikiran), tangan (perilaku/tindakan), dan hati (perasanaan/cinta kasih) sesama manusia dan makhluk hidup lainnya. Itulah yang kemudian harus menjadi esensi dari pembelajaran sejarah untuk menciptakan manusia yang berkarakter.

Namun kenyataannya pembelajaran sejarah pada saat ini masih kurang diminati oleh peserta didik. Sehingga pembentukan karakter melalui pembelajaran sejarah seringkali mengalami kesulitan. Hingga saat ini pendidikan sejarah di sekolah masih berkutat pada pendekatan cronicle dan cenderung menuntut anak agar menghapal sesuatu peristiwa. Siswa tidak dibiasakan untuk mengartikan suatu peristiwa guna memahami dinamika suatu perubahan. Untuk siswa sekolah menengah, sejarah harusnya menjadi alat untuk memahami segala macam peristiwa yang terjadi. Mereka sudah seharusnya dibiasakan berdialog dengan lingkungan, memilih-milih persoalan yang ada, sehingga mereka biasa memahami adanya dinamika dari suatu perubahan. Berdasarkan hasil observasi proses pembelajaran sejarah di kelas X SMA Negeri 3 Banjar diketahui bahwa peserta didik belum mampu menguasai materi tentang kerajaan-kerajaan Islam di Indonesia. Indikasi ketidakmampuan peserta didik tersebut yakni belum bisa menginterpretasikan materi yang disampaikan guru. Ketidakmampuan dalam menguasi materi tersebut didasari karena pengajaran yang diberikan kepada peserta didik kurang tepat dan kurang efektif, sehingga menjadi tidak fokus dan sulit memahami materi yang disampaikan. Dengan demikian kemampuan peserta didik dalam menguasai materi tidak berkembang secara optimal. Kemudian melihat dari nilai yang diperoleh dalam proses pembelajaran sebelumnya masih banyak yang mendapatkan nilai kurang dari Kriteria Ketuntasan Minimal (KKM). Hal ini tampak dari hasil tes, diketahui dari 30 peserta didik, yang berhasil mencapai KKM hanya 5 siswa, sedangkan sisanya masih jauh dari KKM.

Untuk mencapai keberhasilan tersebut, maka guru harus pandai memilih metode yang sesuai materi pembelajaran. Pembelajaran yang baik adalah pembelajaran yang menitik beratkan pada pengembangan minat perilaku yang didasarkan pada kebutuhan peserta didik itu sendiri, karena belajar aktif harus berpusat pada peserta didik (Ulfa, 2016). Menciptakan suasana pembelajaran kondusif dan menyenangkan perlu adanya pengemasan model pembelajaran yang menarik. Agar upaya tersebut berhasil maka harus dipilih model pembelajaran yang sesuai dengan situasi dan kondisi peserta didik serta lingkungan belajar, supaya peserta didik dapat aktif, interaktif dan kreatif dalam proses pembelajaran. Maka model pembelajaran yang digunakan guru seharusnya dapat membantu proses analisis peserta didik. Salah satu model tersebut adalah model PBL (Problem Based Learning) yang bermaksud memberikan ruang gerak berpikir bebas siswa untuk mencari konsep dan menyelesaikan masalah terkait dengan materi yang disampaikan oleh guru. Karena pada dasarnya ilmu sejarah bertujuan agar siswa memahami konsep-konsep sejarah dengan kehidupan sehari-hari. Pembelajaran dengan model PBL menghadirkan situasi nyata 
kehidupan siswa sehingga siswa tidak bingung dan dapat langsung memahami dan menemukan sendiri apa yang dipelajari khususnya pada pelajaran sejarah. Model pembelajaran ini juga banyak melibatkan siswa secara aktif dalam proses pembelajaran. Siswa diberikan kebebasan untuk lebih berpikir dalam mengembangkan penalarannya tersebut dalam menyelesaikan permasalahan yang dihadapinya. Model pembelajaran PBL diharapkan sesuai untuk diterapkan, agar siswa lebih mudah memahami materi sehingga dapat meningkatkan karakter siswa. Berdasarkan latar bekang di atas dan dasar pemikiran tersebut, penulis akan melakukan penelitian dengan judul "Model Pembelajaran Problem Based Learning dalam Pembelajaran Sejarah untuk Meningkatkan Karakter Siswa di Kelas X SMA Negeri 3 Banjar".

\section{METODE PENELITIAN}

Jenis penelitian yang digunakan adalah Penelitian Tindakan Kelas (PTK) yang diarahkan untuk memecahan masalah atau perbaikan. Guru-guru mengadakan pemecahan terhadap masalahmasalah yang dihadapi dalam kelas, kepala sekolah mengadakan perbaikan terhadap manajemen di sekolahnya (Mahmud \& Priatna, 2008). Sependapat dengan penjelasan di atas Kemmis juga menjelaskan penelitian tindakan adalah studi yang sistematis untuk memperbaiki praktik pendidikan oleh sekelompok peneliti dengan tujuan memperbaiki sesuatu dengan ide dan gagasan dari peneliti (Winarno, Muarifin, \& Budiwanto, 2012). Dengan demikian penelitian tindakan kelas adalah penelitian yang dilakukan di kelas yang bertujuan memperoleh informasi mengenai seberapa efektif gagasan atau ide peneliti dalam memperbaiki sebuah masalah. Peneliti menggunakan penelitian PTK bentuk kolaboratif, yang melibatkan beberapa pihak, baik guru, kepala sekolah, maupun dosen secara serentak, tujuannya untuk meningkatkan praktik pembelajaran, menyumbang pada perkembangan teori, dan peningkatan karier guru. Model penelitian tindakan seperti ini selalu dirancang dan dilaksanakan oleh tim yang terdiri dari guru, dosen, dan kepala sekolah.

\section{HASIL DAN PEMBAHASAN}

\section{Temuan Hasil Penelitian Siklus I dan Siklus II}

Data mengenai hasil belajar peserta didik sebelum tindakan (pre test) siklus I digunakan untuk mengetahui nilai peserta didik sebelum dilaksanakan tindakan siklus I dan (post test) untuk mengukur sejauh mana keberhasilan setelah dilakukannya tindakan siklus I. Sedangkan data mengenai hasil belajar peserta didik sebelum tindakan (pre test) siklus II digunakan untuk mengetahui nilai peserta didik sebelum dilaksanakan tindakan siklus II dan (post test) untuk mengukur sejauh mana keberhasilan setelah dilakukannya tindakan siklus II. Adapun hasil diperoleh dapat dilihat dalam tabel berikut ini:

Tabel 1.

Hasil Evaluasi Nilai Belajar Siswa Siklus I

\begin{tabular}{|c|l|c|c|}
\hline No & Hasiltes siklus 1 & Pre test & Post test \\
\hline 1 & Nilai tertinggi & 60 & 68 \\
\hline 2 & Nilai terendah & 40 & 44 \\
\hline 3 & Rata-rata nilai & 48 & 56 \\
\hline \multicolumn{2}{|c|}{ Jumlah siswa tuntas } & 0 & 0 \\
\hline \multicolumn{2}{|c|}{ Jumlah siswa tidak tuntas } & 30 & 30 \\
\hline
\end{tabular}

Tabel 2.

Hasil Evaluasi Nilai Hasil Belajar Siswa Siklus II

\begin{tabular}{|c|l|c|c|}
\hline No & Hasil tes siklus 1 & Pre test & Post test \\
\hline 1 & Nilai tertinggi & 75 & 85 \\
\hline 2 & Nilai terendah & 60 & 75 \\
\hline 3 & Rata-rata nilai & 66 & 77 \\
\hline \multicolumn{2}{|c|}{ Jumlah siswa tuntas } & 7 & 30 \\
\hline \multicolumn{2}{|c|}{ Jumlah siswa tidak tuntas } & 23 & 0 \\
\hline
\end{tabular}

Berdasarkan Tabel 2 di atas dapat diperoleh informasi bahwa dari siswa terperinci jumlah siswa tuntas dalam Pree Test yaitu 7 orang siswa dan jumlah siswa tidak tuntas yaitu 23 orang siswa, sedangkan pada Post Test seluruh siswa tuntas yaitu 30 orang siswa.

\section{Pelaksanaan Pembelajaran Sejarah Dengan Penerapan Model Pembelajaran PBL}

\section{a. Penelitian pendahuluan (Pra siklus)}

Indikator capaian keberhasilan dalam proses pembelajaran sejarah dengan menerapkan model pembelajaran Problem Based Learning, yaitu karakter peserta didik meningkat dan hasil belajar mencapai $\geq 70 \%$ serta nilai rata-rata tes $\geq 70$. Peneliti menggunakan angket karakter 
peserta didik untuk mengetahui persentase karakter peseta didik. Dalam menentukan skor dari angket tersebut, maka system scoring menggunakan skala Likert dengan 4 pilihan jawaban yaitu Sangat setuju (SS), Setuju (S), Tidak setuju (TS), dan Sangat tidak setuju (STS). Untuk pernyataan positif skala yang digunakan adalah $4,3,2$, dan 1 sedangkan untuk penyataan negatif $1,2,3$, dan 4 . Setelah data didapat, maka perolehan sekor dirubah menjadi presentase untuk menentukan apakah siswa setuju, netral ataupun tidak setuju mengenai angket yang diberikan. Keseluruhannya diperoleh dengan menjumlahkan seluruh skor butir pertanyaan. Diketahui skor tertinggi $(X)$ adalah 116 poin dan skor terendah $(Y)$ adalah 35 Hasil penilaian angket motivasi siswa dalam pembelajaran sejarah sebagai berikut:

Tabel 3.

Hasil penilaian angket kretifitas belajar

\begin{tabular}{|c|c|c|c|c|c|c|c|}
\hline Point & SS & $\mathbf{S}$ & $\mathrm{T}$ & ST & $\begin{array}{l}\text { Por } \\
\text { Sen } \\
\text { Tase }\end{array}$ & jml & Kesimpulan \\
\hline 1 & 26 & 4 & 0 & 0 & $97 \%$ & 116.0 & Sangat Setuju \\
\hline 2 & 0 & 26 & 2 & 2 & $70 \%$ & 84.0 & Setuju \\
\hline 3 & 18 & 12 & 0 & 0 & $90 \%$ & 108.0 & Sangat Setuju \\
\hline 4 & 0 & 0 & 16 & 14 & $38 \%$ & 46.0 & tidak setuju \\
\hline 5 & 5 & 8 & 10 & 7 & $59 \%$ & 71.0 & Netral \\
\hline 6 & 5 & 25 & 0 & 0 & $79 \%$ & 95.0 & Setuju \\
\hline 7 & 8 & 12 & 7 & 3 & $71 \%$ & 85.0 & Setuju \\
\hline 8 & 0 & 0 & 15 & 15 & $38 \%$ & 45.0 & tidak setuju \\
\hline 9 & 2 & 18 & 3 & 7 & $63 \%$ & 75.0 & Setuju \\
\hline 10 & 8 & 17 & 3 & 2 & $76 \%$ & 91.0 & Setuju \\
\hline 11 & 12 & 10 & 4 & 4 & $75 \%$ & 90.0 & Setuju \\
\hline 12 & 13 & 17 & 0 & 0 & $86 \%$ & 103.0 & Sangat Setuju \\
\hline 13 & 0 & 0 & 17 & 13 & $39 \%$ & 47.0 & tidak setuju \\
\hline 14 & 10 & 6 & 12 & 2 & $70 \%$ & 84.0 & Setuju \\
\hline 15 & 17 & 8 & 3 & 2 & $83 \%$ & 100.0 & Sangat Setuju \\
\hline 16 & 0 & 0 & 12 & 18 & $35 \%$ & 42.0 & tidak setuju \\
\hline 17 & 3 & 10 & 7 & 10 & $55 \%$ & 66.0 & Netral \\
\hline 18 & 13 & 17 & 0 & 0 & $86 \%$ & 103.0 & Sangat Setuju \\
\hline 19 & 5 & 4 & 11 & 10 & $53 \%$ & 64.0 & Netral \\
\hline 20 & 6 & 12 & 10 & 2 & $68 \%$ & 82.0 & Setuju \\
\hline 21 & 16 & 14 & 0 & 0 & $88 \%$ & 106.0 & Sangat Setuju \\
\hline 22 & 12 & 18 & 0 & 0 & $85 \%$ & 102.0 & Sangat Setuju \\
\hline 23 & 19 & 11 & 0 & 0 & $91 \%$ & 109.0 & Sangat Setuju \\
\hline 24 & 9 & 11 & 10 & 0 & $74 \%$ & 89.0 & Setuju \\
\hline 25 & 2 & 10 & 7 & 11 & $53 \%$ & 63.0 & Netral \\
\hline 26 & 0 & 0 & 12 & 18 & $35 \%$ & 42.0 & tidak setuju \\
\hline 27 & 11 & 14 & 3 & 2 & $78 \%$ & 94.0 & Setuju \\
\hline 28 & 19 & 11 & 0 & 0 & $91 \%$ & 109.0 & Sangat Setuju \\
\hline 29 & 4 & 6 & 6 & 14 & $50 \%$ & 60.0 & Netral \\
\hline 30 & 7 & 8 & 9 & 6 & $63 \%$ & 76.0 & Setuju \\
\hline 31 & 12 & 8 & 7 & 3 & $74 \%$ & 89.0 & Setuju \\
\hline 32 & 9 & 6 & 7 & 8 & $63 \%$ & 76.0 & Setuju \\
\hline 33 & 2 & 3 & 12 & 13 & $45 \%$ & 54.0 & Netral \\
\hline 34 & 3 & 4 & 11 & 12 & $48 \%$ & 58.0 & Netral \\
\hline 35 & 17 & 13 & 0 & 0 & $89 \%$ & 107.0 & Sangat Setuju \\
\hline 36 & 12 & 7 & 5 & 6 & $71 \%$ & 85.0 & Setuju \\
\hline
\end{tabular}

\begin{tabular}{|c|c|c|c|c|c|c|c|}
\hline 37 & 6 & 4 & 8 & 12 & $53 \%$ & 64.0 & Netral \\
\hline 38 & 21 & 9 & 0 & 0 & $93 \%$ & 111.0 & Sangat Setuju \\
\hline 39 & 3 & 4 & 12 & 11 & $49 \%$ & 59.0 & Netral \\
\hline 40 & 4 & 2 & 13 & 11 & $49 \%$ & 59.0 & Netral \\
\hline 41 & 2 & 3 & 3 & 12 & $29 \%$ & 35.0 & tidak setuju \\
\hline 42 & 15 & 7 & 8 & 0 & $81 \%$ & 97.0 & Sangat Setuju \\
\hline 43 & 0 & 2 & 17 & 11 & $43 \%$ & 51.0 & Netral \\
\hline 44 & 0 & 3 & 14 & 13 & $42 \%$ & 50.0 & Netral \\
\hline 45 & 0 & 0 & 11 & 19 & $34 \%$ & 41.0 & tidak setuju \\
\hline 46 & 3 & 3 & 11 & 4 & $39 \%$ & 47.0 & tidak setuju \\
\hline 47 & 5 & 14 & 6 & 5 & $66 \%$ & 79.0 & Setuju \\
\hline 48 & 21 & 9 & 0 & 0 & $93 \%$ & 111.0 & Sangat Setuju \\
\hline 49 & 3 & 4 & 12 & 11 & $49 \%$ & 59.0 & Netral \\
\hline 50 & 4 & 2 & 13 & 11 & $49 \%$ & 59.0 & Netral \\
\hline 51 & 2 & 3 & 3 & 12 & $29 \%$ & 35.0 & tidak setuju \\
\hline 52 & 15 & 7 & 8 & 0 & $81 \%$ & 97.0 & Sangat Setuju \\
\hline 53 & 0 & 2 & 17 & 11 & $43 \%$ & 51.0 & Netral \\
\hline 54 & 0 & 3 & 14 & 13 & $42 \%$ & 50.0 & Netral \\
\hline 55 & 0 & 0 & 11 & 19 & $34 \%$ & 41.0 & tidak setuju \\
\hline 56 & 3 & 3 & 11 & 4 & $39 \%$ & 47.0 & tidak setuju \\
\hline 57 & 5 & 14 & 6 & 5 & $66 \%$ & 79.0 & Setuju \\
\hline 58 & 2 & 18 & 3 & 7 & $63 \%$ & 75.0 & Setuju \\
\hline 59 & 8 & 17 & 3 & 2 & $76 \%$ & 91.0 & Setuju \\
\hline 60 & 12 & 10 & 4 & 4 & $75 \%$ & 90.0 & Setuju \\
\hline 61 & 13 & 17 & 0 & 0 & $86 \%$ & 103.0 & Sangat Setuju \\
\hline 62 & 0 & 0 & 17 & 13 & $39 \%$ & 47.0 & tidak setuju \\
\hline 63 & 10 & 6 & 12 & 2 & $70 \%$ & 84.0 & Setuju \\
\hline 64 & 17 & 8 & 3 & 2 & $83 \%$ & 100.0 & Sangat Setuju \\
\hline 65 & 0 & 0 & 12 & 18 & $35 \%$ & 42.0 & tidak setuju \\
\hline 66 & 3 & 10 & 7 & 10 & $55 \%$ & 66.0 & Netral \\
\hline 67 & 13 & 17 & 0 & 0 & $86 \%$ & 103.0 & Sangat Setuju \\
\hline 68 & 5 & 4 & 11 & 10 & $53 \%$ & 64.0 & Netral \\
\hline 69 & 6 & 12 & 10 & 2 & $68 \%$ & 82.0 & Setuju \\
\hline 70 & 12 & 7 & 5 & 6 & $71 \%$ & 85.0 & Setuju \\
\hline 71 & 6 & 4 & 8 & 12 & $53 \%$ & 64.0 & Netral \\
\hline 72 & 21 & 9 & 0 & 0 & $93 \%$ & 111.0 & Sangat Setuju \\
\hline
\end{tabular}

Dari data angket dapat diketahui; pertama, jumlah pernyataan positif yang disetujui peseta didik adalah sebanyak 28 poin dengan 16 pernyataan sangat disetujui peserta didik. Kedua, terdapat 14 pernyataan negatif yang disetujui peserta didik dengan 2 pernyataan negatif sangat disetujui oleh peserta didik. Ketiga, terdapat 2 pernyataan positif yang tidak disetujui dan 9 pernyataan negatif ditolak oleh peserta didik. Keempat, terdapat 13 penyataan negatif ditanggapi netral oleh peserta didik dan terdapat 6 pernyataan positif yang ditanggapi netral. Bisa disimpulkan $77 \%$ pernyataan positif yang disetujui, $5,5 \%$ pernyataan positif yang ditolak peserta didik, $16,6 \%$ penyataan positif ditanggapi biasa saja atau netral. Selanjutnya untuk pernyataan negatif, terdapat $38,9 \%$ dissetujui, $25 \%$ penyataan ditolak dan $36 \%$ pernyataan ditanggapi netral. 
Dengan demikian peserta didik memiliki karakter yang beragam dengan karakter positif lebih menonjol 38,1\% dari karakter negatif.

\section{b. Tindakan Siklus I}

\section{a) Perencanaan tindakan pada siklus 1 (acting)}

Hal yang dilakukan yaitu; menentukan kelas yang akan dijadikan objek penelitian, yakni kelas X IPS. Selanjutnya melakukan kegiatan observasi mengenai kegiatan pembelajaran. Mendiskusikan serta Menyusun Rencana Persiapan Pembelajaran (RPP), menentukan Standar Kompetensi (SK), Kompetensi Dasar (KD) dan Indikator sesuai dengan Kurikulum 2013. Penulis memilih kompetensi dasar (KD) Menganalisis cara berpikir diakronik dan sinkronik dalam karya sejarah, menyiapkan soal diskusi kelompok, menyiapkan soal pre test dan post test, membentuk kelompok diskusi belajar menjadi 5 kelompok. Kemudian guru menjelaskan kegiatan yang harus dilakukan pada saat diskusi kelompok dan menjelaskan tujuan pencapaian pembelajaran. Dengan menyiapkan beberapa pokok masalah kontemporer untuk didiskusikan, menentukan alokasi waktu 2 x 45 menit dan pembelajaran menggunakan model pembelajaran Problem Based Learning serta metode ceramah sebagai pendukung kegiatan belajar mengajar di kelas.

\section{b) Pelaksanaan tindakan pada siklus 1 (acting)}

Pelaksanaan kegiatan pembelajran siklus I dilaksanakanpada hari kamis 5 september 2019 di kelas X IPS SMA N 3 Banjar berjumlah 30 peserta didik. Guru mitra merupakan pengamat dan peneliti sebagai objek yang diamati menggunakan model pembelajaran Problem Based Learningdalam materi kompetensi dasar (KD) Menganalisis cara berpikir diakronik dan sinkronik dalam karya sejarah. Penelitian dilaksanakan sejumlah 2 siklus. Setiap siklus terdiri dari satu kali pertemuan. Setiap minggunya masing-masing kelas mendapatkan 2 jam pelajaraan sejarah. Penelitian ini menggunakan waktu 2 jam pelajaran yaitu dengan alokasi waktu 2X45 menit, dengan waktu tersebut cukup untuk melakukan penelitian yang dimulai dari perencanaan, tindakan, pengamatan dan refleksi.

\section{c) Observasi Siklus 1}

Pada siklus I, kegitan pembelajaran telah menggunakan metode pembelajaran Problem Based Learning, yakni belajar antara peserta didik dan peserta didik, dan antara peserta didik dengan guru. Dilakukan pre test terlebih dahulu sebelum kegiatan pembelajaran dilakukan. Selanjutnya proses belajar mengajar dilakukan selama 60 menit menggunakan metode pembelajaran Problem Based Learning dengan materi cara berpikir sinkronis dan diakronis dalam karya sejarah.

\section{d) Refleksi Siklus I (reflecting)}

Dalam pembelajaran pada siklus I peneliti mengalami kesulitan dalam mengelola waktu yang ada karena diskusi berjalan lama disebabkan siswa belum siap untuk melakukan diskusi. Siswa masih perlu dipaksa untuk berani mengungkapkan pendapatnya dalam diskusi kelompok. Selain itu, siswa masih mengandalkan satu dua orang dalam berdiskusi. Hasil kegiatan pembelajaran pada siklus I belum mencapai nilai maksimal. Sehingga perlunya dilaksanakan kembali penelitian siklus 2. Berdasarkan penelitian siklus I dapat dikatakan sudah adanya peningkatan, akan tetapi belum maksimal. Maka akan dilaksanakan siklus II.

\section{c. Tindakan Siklus II}

\section{a) Perencanaan Tindakan Siklus II (planning)}

Untuk memperbaiki pelaksanaan siklus I, kemudian peneliti melakukan perencanaan siklus II. Dalam pelaksanaan siklus ini, guru mengajar sesuai dengan langkah-langkah pemebelajaran yang terdapat dalam Rencana Pelaksanaan Pembelajaran (RPP) dengan kompetensi dasar (KD) Menganalisis cara berpikir diakronik dan sinkronik dalam karya sejarah. Metode yang digunakan dalam pembelajaran adalah ceramah, diskusi kelompok dengan model pembelajaran problem based leraning. Penilaian yang digunakan adalah hasil pre test, angket perkembangan karakter peserta didik dan post test. Dalam proses 
pembelajaran guru memantau kegiatan pembelajaran agar sesuai dengan langkah-langkah model Problem Based Learning. Diakhir pembelajaran guru menutup pelajaran dengan menyimpulkan materi pembelajaran.

\section{b) Pelakssanaan Tindakan Siklus II}

Pelaksanaan kegiatan pembelajaran siklus II dilaksanakan pada hari kamis, 12 september di kelas X IPS SMA N 3 Banjar. Guru mitra merupakan pengamat dan peneliti sebagai objek yang diamati menggunakan model pembelajaran Problem Based Learning dalam materi Kompetensi Dasar cara berpikir sinkronis dan diakronis dalam karya sejarah. Proses pembelajaran mengacu pada Rencana Pelaksanaan Pembelajaran (RPP) yang telah dipersiapkan peneliti.

\section{c) Refleksi Siklus II (Reflecting)}

Refleksi pada siklus II dapat dilihat lebih baik dari siklus I. Pada siklus II hasil belajar dan motivasi siwa telah lebih meningkat dibandingkan dengan siklus I, peserta didik lebih peracaya diri dengan kemampuan yang mereka miliki sehingga dengan mudah dapat bekerjasama, peserta didiksudah memahami materi yang disampaikan guru, dan seluruh peserta didik mengikuti pembelajaran dengan baik. Hasil dari penelitian ini maka dapat direfleksikan bahwa terjadi adanya peningkatan karakter peserta didik. Peneliti menyimpulkan bahwa siklus II ini merupakan keberhaslian pembelajaran sejarah dengan model pembelajaran Problem Based Learning dan penelitian diakhiri sampai siklus II.

\section{Hasil Model Pembelajaran Problem Based Learning}

Pada penelitian ini dapat diketahui bawa dengan diterapkannya pembelajaran dengan model pembelajaran Problem Based Learning, karakter siswa mengalami peningkatan. Perubahan tersebut dapat diketahui dari hasil observasi terhadap karakter siswa selama pembelajaran berlangsung dan melalui angket yang diberikan; pertama, jumlah siswa setuju dalam poin positif dalam angket mengalami peningkatan; kedua, $55 \%$ poin disetujui oleh peserta didik, $26 \%$ poin disikapi netral dan $18 \%$ poin tidak disetujui peserta didik. Pada siklus I, hasil belajar selama pembelajaran sejarah dengan model Problem Based Learning dari 30 siswa diperoleh nilai rata-rata post test 56 sedangkan pada siklus II diperoleh nilai rata-rata 77. Dari data tersebut dapat disimpulkan bahwa model ini mampu meningkatkan hasil belajar siswa. Merunut pada persyaratan kesuksesan penelitian dengan capaian KKM 75.

Tabel 4.

Rekapitulasi kreatifitas belajar peserta didik

\begin{tabular}{|l|l|}
\hline Siklus & Skor (\%) \\
\hline Siklus I & 56 \\
\hline Siklus II & 77 \\
\hline
\end{tabular}

\section{KESIMPULAN}

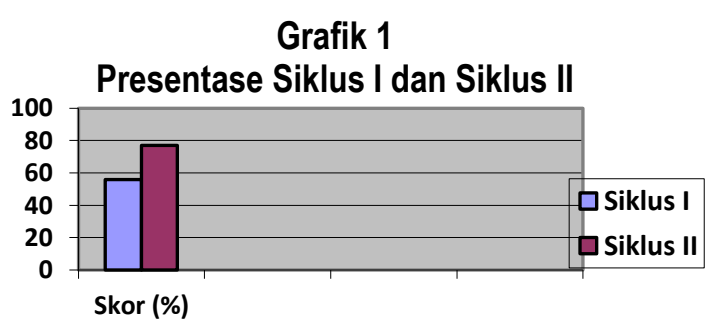

Berdasarkan hasil penelitian dapat ditarik kesimpulan bahwa "Model Pembelajaran Problem Based Learning dalam Pembelajaran Sejarah untuk Meningkatkan Karakter Siswa di Kelas X SMA Negeri 3 Banjar" dapat meningkatkan karakter siswa. Peningkatan karakter siswa dapat dilihat dari hasil observasi selama pembelajaran berlangsung dan melalui angket yang diberikan; Bisa disimpulkan $77 \%$ pernyataan positif yang disetujui, $5,5 \%$ pernyataan positif yang ditolak peserta didik, $16,6 \%$ penyataan positif ditanggapi biasa saja atau netral. Selanjutnya untuk pernyataan negatif, terdapat $38,9 \%$ dissetujui, $25 \%$ penyataan ditolak dan 36\% pernyataan ditanggapi netral. Dengan demikian peserta didik memiliki karakter yang beragam dengan karakter positif lebih menonjol $38,1 \%$ dari karakter negatif. Pada siklus I, hasil belajar selama pembelajaran sejarah dengan model Problem Based Learning dari 30 siswa diperoleh nilai rata-rata post test 56 sedangkan pada siklus II diperoleh nilai rata-rata 77. Dari data ini dapat disimpulkan juga bahwa 
model ini mampu meningkatkan hasil belajar siswa. Merunut pada persyaratan kesuksesan penelitian dengan capaian KKM 75.

Dengan demikian maka penerapan model Pembelajaran Problem Based Learning dalam Pembelajaran Sejarah untuk Meningkatkan Karakter Siswa di Kelas X SMA Negeri 3 Banjar dapat dikatakan berhasil dan mencapai target yang telah ditentukan yaitu meningkatnya karakter peserta didik $\geq 70 \%$ dan hasil belajar mencapai nilai rata-rata tes $\geq 70$ terlampaui. Hal ini didasarkan pada guru sudah mampu menerapkan model pembelajaran dengan baik, sehingga tercipta proses pembelajaran yang aktif dan berpusat pada peserta didik serta dapat meningkatkan karakter maupun pemahaman peserta didik terhadap materi yang diajarkan. Sedangkan peserta didik didorong untuk lebih aktif dalam mencari informasi atau materi pembelajaran sehingga pengetahuan yang dimiliki peserta didik akan lebih banyak dan tidak bergantung pada guru.

\section{REKOMENDASI}

Guru diharapkan dapat menggunakan model-model pembelajaran yang kreatif dan inovatif agar minat dan hasil belajar sejarah peserta didik dapat lebih meningkat dan maksimal. Salah satu model pembelajaran sejarah yang dapat digunakan adalah model pembelajaran Problem Based Learning dalam menganalisis materi tentang kerajaan-kerajaan Islam di Indonesia untuk meningkatkan karakter siswa.

\section{UCAPAN TERIMA KASIH}

Penulis mengucapan terima kasih kepada guru Sejarah dan siswa kelas $X$ Siswa SMA Negeri 3 Banjar, serta pihak-pihak terkait yang telah mendukung kelancaran terhadap penelitian ini.

\section{DAFTAR PUSTAKA}

Asmara, R. A., Heryati, T \& Patonah, R. (2021). Pengaruh Lingkungan Teman Sebaya terhadap Prestasi Belajar Peserta Didik pada Mata Pelajaran Akuntansi di SMK Swadaya Karangnunggal. J-KIP (Jurnal Keguruan dan IImu Pendidikan), 2 (1), 71-78.

Hasan, H. 2011. "Pendidikan Sejarah: Orientasi dan Strategi Pedagogis." Makalah Pada.Konferensi Nasional Sejarah IX.

Koesoema, D. 2010. Pendidikan Karakter: Strategi Mendidik Anak di Zaman Global. Jakarta: Grasindo.

Mahmud, \& Priatna, T. 2008. Penelitian Tindakan Kelas (Teori dan Praktik. Bandung: Tsabita.

Sagala, S. 2011. Konsep dan Makna Pembelajaran. Bandung: Alfabeta.

Susanto, H. 2014. Seputar Pembelajaran Sejarah (Isu, Gagasan dan Strategi Pembelajaran). Yogyakarta: Aswaja Pressindo.

Tim pengembang IImu Pendidikan FIP-UPI. 2007. IImu Dan Aplikasi Pendidikan. Jakarta: Imperial Bakti Utama.

Ulfa, N. 2016. Pengaruh Model Pembelajaran PBL (Problem Based Learning) Terhadap Hasil Belajar Siswa Pada Materi Bahan Kimia Dalam Kehidupan Sehari-Hari Di Kelas VIII SMPN 1 Sukamakmur. Skripsi. Banda Aceh. Universitas Islam Negeri Ar-Raniry: [tidak diterbitkan].

Winarno, M. E., Muarifin, \& Budiwanto, S. 2012. Penelitian Tindakan Kelas dan Karya IImiah Penjaskes SD. Kementerian Pendidikan Dan Kebudayaan Universitas Negeri Malang Panitia Sertifikasi Guru (PSG) Rayon 15. 